\title{
Announcements
}

Call for Papers: A special issue of The Joumal of Speculative Philosophy devoted to

\section{Pragmatism and Feminism}

Seven years now have passed since the feminist philosophy journal Hypatia devoted a special issue to the topic of pragmatism and feminism, edited by Charlene Haddock Seigfried. In the tradition of that important volume, The Journal of Speculative Philosophy seeks papers on any aspect of the intersection of pragmatism and feminism for a special issue to be guest-edited by Shannon Sullivan. Possible topics include (but are not limited to):

- feminist critiques of either historical or contemporary pragmatism

- pragmatist critiques of either historical or contemporary feminism

- pragmatist-feminist approaches to contemporary issues

- the work of historical figures in pragmatist feminism

Send one hard copy of your paper (no email attachments please) to:

Shannon Sullivan

Department of Philosophy

240 Sparks Building

Penn State University

University Park, PA 16802

Submission deadline: December 31, 2000

Questions? Contact Shannon Sullivan at sws10@psu.edu or (814) 865-1618.

Funding: The Rosenberg Fund for Children

The Rosenberg Fund for Children (RFC) is a public foundation that provides for the educational and emotional needs of children in this country whose parents have been harassed, injured, lost jobs, or died in the course of their progressive activities. Institutions and professionals are awarded grants to provide these children with services (school tuition, music lessons, summer camp, therapy, day care, travel to visit an incarcerated relative, etc.). Grants are given directly to institutions and individuals who cultivate positive human values, and foster children's physical, mental, emotional, and cultural develop- 
ment while recognizing that children must be free to be children. The RFC was founded by Robert Meeropol, the younger son of Julius and Ethel Rosenberg, who was 6 years old when his parents were executed.

RFC beneficiaries include the children of: Judi Bari, the well-known environmental activist; Mumia Abu-Jamal, a political prisoner currently on death row in Pennsylvania; and Mary Pitawanakwat, an indigenous woman who fought against racial and sexual harassment in her workplace. (The RFC protects the anonymity of its beneficiaries, and mentions these individuals only with their consent.)

If you know of a child of a targeted activist who might qualify for an RFC grant, or for more information, contact the Rosenberg Fund for Children at rfc@rfc.org; www.rfc.org; 413-739-9020; or 1145 Main St. \#408, Springfield, MA, 01103.

\section{Call for Papers: PHILOSOPHY NOW magazine}

1. Philosophy Now is a magazine designed to appeal both to specialists AND to the general public. The majority of our readers have had no formal training in philosophy and contributors should write with them in mind.

2. Articles should be self-contained; it shouldn't be necessary for readers to look up references in order to follow what is being said. The one exception to this rule is for articles which form part of a debate conducted within the magazine.

3. Jargon. We're against it. If the use of technical terms is unavoidable, please include a brief explanation of their meaning within your article.

4. To help ensure maximum clarity, ask an intelligent, educated friend who knows no philosophy to read your article before you send it in and, if necessary, modify it in the light of his/her comments.

5. Articles should be between 1000 and 3500 words long, while book reviews should be of less than 1500 words. Please indicate exact number of words and include a short ( 50 word) abstract (just for filing purposes, not for publication).

6. Pictures. Any illustrations should accompany the manuscript but be separate from it. Photographs are welcomed too (ideally black and white prints).

7. Copyright on articles remains the property of the authors. Authors are free to publish their contributions again elsewhere, if Philosophy Now is acknowledged as the place of first publication.

8. Unfortunately, we are not able to pay authors for articles. However, all contributors whose work is published will receive a free subscription to Philosophy Now.

9. Wherever possible, articles will be vetted by referees competent in the relevant area of philosophy. However, the decision of the Editor to accept or 
decline papers for publication will be final, arbitrary, frequently unjust and utterly irrevocable.

Contributions should be sent to:

Anja Steinbauer, Philosophy Now, 25 Blandfield Rd London SW12 8BQ UK

\section{Call for Papers: JAC}

$J A C$ invites the submission of articles on a variety of topics related to writing, rhetoric, literacy, culture, and radical pedagogy. We also invite theoretical articles on multiculturalism and the politics of difference. JAC seeks to support crossdisciplinary conversation by publishing scholarship that finds in contemporary theory the language to ask new questions, to reframe existing problems, and to move beyond current impasses in though and action. Also of interest are articles that make available a theoretical understanding of important professional issues in the classroom techniques, we do invite submissions on pedagogical theory. Please use current MLA style and send three copies, stripped of any identifying information, for blind review. Direct submissions and inquiries to: University of South Florida; Tampa, FL 33620-5550; (813) 974-9536; Lworsham@chumal.cas.usf.edu.

Press Release: RLF Event

\section{Radical Lesbian Feminist Uprising! \\ October 26-29, 2000 \\ Near Kansas City, Missouri}

All radical lesbian feminists are invited to attend this Uprising! Lesbians who are seriously considering becoming radical lesbian feminists are also welcome to attend. Activities will include workshops, small group discussions, community meetings, good food and our own home-grown fun. Expect political discussions and personal connections. The lesbians attending will create all events. Bring what you need to take part!

Important information about the event:

Where: A rural conference center/camp north of Kansas City, MO. 
Accommodations: Multiple occupancy rooms with bunk beds. A few private rooms available. Heat, air conditioning, and hot showers.

Accessibility: There is a limited number of wheelchair accessible rooms. Please contact us about any disability-related accommodations or other specific needs as soon as possible.

Please do not wear scented body products (soap, shampoo, deodorant, cologne, perfume, etc.) or clothes scented by detergents or fabric softeners. Some of the dykes attending are made ill by any exposure to such products.

Cost: Sliding scale $\$ 0-60$ per night, more if you can.

Food: Vegetarian, vegan options.

Policies: The purpose of the Uprising is to discuss and practice radical lesbian feminist concepts, including the challenging of oppressions in an honest, caring and respectful way. This event is open to lesbians who are womyn born womyn. It is only for radical lesbian feminists or lesbians who are seriously considering becoming radical lesbian feminists. It is not open to lesbians who practice or advocate sadomasochism or pornography or who are in the process of taking male hormones for transsexual or transgender purposes.

For more information contact:

Mail: RLF, Box 112, St. Paul, AR 72760

Email: jfneath@mindspring.com

Telephone: Jeanne Neath (501) 677-2235

Society for Women in Philosophy

For information on SWIP membership, which includes receiving program announcements, the national SWIP newsletter, and a discount subscription to Hypatia, contact the SWIP chapter in your area:

Eastern SWIP: Executive Secretary: Wendy Lee-Lampshire, Department of Philosophy, 219 Bakeless Center for the Humanities, Bloomsburg University, Bloomsburg, PA 17815. (lampshire@planetx.bloomu.edu). Treasurer: Nancy Stanlick, 1940 19th St. NW, Winter Haven, Florida. (stanlick@aol.com)

Midwest SWIP: Executive Secretary: Jacqueline Anderson, Dept. of Humanities, City College of Chicago, Olive-Harvey College, Chicago, IL 60628. Treasurer: Amber Katherine, Philosophy Department, Santa Monica College, 1900 Pico Blvd., Santa Monica, CA 90405-1628. (KATHERINE_AMBER @smc.edu)

Pacific SWIP: Executive Secretary: Betsy Decyk, Philosophy, California State University, Long Beach, 1250 Bellflower Boulevard, Long Beach, CA 
90840; phone: (310) 985-4346. (bdecyk@csulb.edu) Treasurer: Renee Lewis, Philosophy Department, California State Los Angeles, Los Angeles, CA 90032-8114.

SWIP- $L$, an electronic mail list for feminist philosophers, is the e-mail information and discussion list for members of the Society for Women in Philosophy and others who are interested in feminist philosophy. To subscribe to this list send the following one-line message: SUBSCRIBE SWIP-L < YOUR NAME> to: SWIP-L@listserv.uh.edu.. When you want to post messages on the list send them to the same address. The purpose of the list is to provide a place to share information about SWIP and other feminist philosophy meetings, calls for papers, jobs for feminist philosophers, etc., as well as to engage in more substantive discussions related to feminist philosophy. While the list is open to both SWIP members and non-members, it is meant for feminist philosophers and theorists. It is free of charge. The SWIP-L's "owner" is Cynthia Freeland. If you have questions please e-mail her at: cfreeland@uh.edu. 